\title{
PIERWSZA HABILITACJA NA PAPIESKIM WYDZIALE TEOLOGICZNYM W KRAKOWIE (9 VI 1968 r.)
}

Po święceniach kapłańskich w dniu 25 czerwca 1950 roku i dwumiesięcznej administracji trzema parafiami na Ziemiach Odzyskanych, administrator apostolski diecezji warmińskiej ks. dr Teodor Bensch, przedwojenny, wojenny i powojenny zastępca profesora na Wydziale Prawa Kanonicznego Katolickiego Uniwersytetu Lubelskiego, skierował neoprezbitera Juliana Wojtkowskiego na studia teologii dogmatycznej w swej macierzystej uczelni. Czynił to z rozdartym sercem wobec ogromnego braku duszpasterzy z jednej strony, a potrzeby kształcenia wykładowców do wskrzeszonego rok wcześniej Warmińskiego Seminarium Duchownego - z drugiej strony. Warunkiem skierowania na studia było zobowiązanie do powrotu na Warmię. Potrzeby diecezji domagały się sprawnego toku studiów. Stąd rada, by iść na seminarium profesora, u którego doktoraty pisze się w wyznaczonym czasie, a mianowicie rektora KUL-u ks. prof. Słomkowskiego, kapłana archidiecezji gnieźnieńskiej po studiach w Strassburgu. Diecezja zwracała koszty utrzymania w konwikcie księży studentów, wynoszące przed zmianą pieniędzy, pod koniec 1950 roku, $9000 \mathrm{zl}$, a po zmianie $-270 \mathrm{zł}$ miesięcznie.

Magisterium teologii, uzyskane w grudniu 1950 roku, i przyjęcie przez Radę Wydziału Teologicznego rozprawy magisterskiej o zasięgu języka polskiego w kazaniach i śpiewie kościelnym na Warmii i Powiślu w połowie XIX wieku ${ }^{1}$ jako pracy licencjackiej, umożliwiło zbieranie materiałów do doktoratu od pierwszego roku studiów począwszy. Wskazany przez promotora kierunek badań: kult Matki Boskiej w Polsce, zaowocował w ciągu dwu lat rozprawą doktorską o wierze w Niepokalane Poczęcie NMP w Polsce w świetle średniowiecznych źródeł liturgicznych ${ }^{2}$. Umożliwiło to powrót do diecezji od 1 lipca 1952 roku i doktorat 21 marca 1953 roku, a postawiło młodego doktora mario-

${ }^{1}$ Zasięg terytorialny języka polskiego w kazaniach na Warmii $i$ Powiślu wedtug akt wizytacyjnych diecezji warmińskiej z lat 1839-1858, „Roczniki Humanistyczne” $4: 1953$ z. 4 s. 217 - 236.

${ }^{2}$ Wiara w Niepokalane Poczęcie NMP w Polsce w świetle średniowiecznych zabytków liturgicznych. Studium historyczno-dogmatyczne, Lublin 1958. 
logii poza gronem wychowanków jedynej w Polsce katedry mariologii o. prof. Ludwika Andrzeja Krupy OFM.

Studia były bardzo obciążające przez natężenie pracy i napięcia zewnętrzne. W ciągu dwu lat zmienili się dwaj kierownicy seminarium teologii dogmatycznej. Po pierwszym roku został usunięty z KUL-u, a potem aresztowany i osadzony w więzieniu ks. Antoni Słomkowski. Po drugim roku został usunięty z KUL o. dr Bogusław Waczyński SJ. Recenzentami pracy doktorskiej zostali księża profesorowie dr hab. Marian Rechowicz, późniejszy biskup administrator apostolski archidiecezji lwowskiej w Lubaczowie, oraz dr hab. Mieczysław Żywczyński. Rodzony ojciec, prof. dr hab. Andrzej Wojtkowski, o młodym doktorze orzekł, że w zakresie rozprawy doktorskiej jest właściwie samoukiem.

Organizm odpowiedział na nadmierny wysiłek anemią, którą dr Zofia Wykowska leczyła angielskimi wyciągami wątrobowymi i skierowała w Tatry. Ksiądz dyrektor „Księżówki” Józef Jasiewicz zgodził się mnie przyjąć i tak rozpoczęła się znajomość ze środowiskiem teologicznym krakowskim. Bywał wtedy w „Księżówce” ks. prof. Ignacy Różycki, świetny narciarz, zapalony i wytrawny taternik, artysta fotograf i teolog, pragnący nadać tej nauce postać zaksjomatyzowaną. Wytworny, elegancki, arystokrata ducha, umiejący zachować dystans wobec otaczającego go świata i ludzi. Przyjeżdżał tu i ostatniego razu zginął śmiercią tragiczną na jezdni przed „Księżówką” ks. prof. Tadeusz Kruszyński, historyk sztuki, absolutnie punktualny jako kapelan sióstr, chodzący w Tatry w stroju góralskim i doskonale mówiący góralską gwarą. Bawił tu też, zwłaszcza zimą, w sezonie narciarskim, ks. prof. Eugeniusz Florkowski, patrolog i historyk dogmatów, lubiany przez wszystkich, choć na równi z poprzednimi otoczony legendą anegdot, wszystkich rzekomo prawdziwych.

Niespodziewany grom uderzył w Wydział Teologiczny Uniwersytetu Jagiellońskiego, gdy wbrew prawu kanonicznemu została powołana do istnienia Akademia Teologii Katolickiej w Warszawie na Bielanach. Ksiądz Eugeniusz Florkowski przeszedł na emeryturę. Ksiądz Ignacy Różycki został prodziekanem Wydziału Teologicznego ATK. Gdy zachorował kierownik katedry historii dogmatów ks. prof. Rosłan, doszło do następującej wymiany listów:

N.B.P.J.CHR.

Kraków dnia 20.5.55.

Czcigodny Księże Profesorze!

Proszę koniecznie przyjechać do Warszawy na Ak. Teol. Kat. i zajść do dziekanatu teologicznego we czwartek 26 b.m. w bardzo ważnej dla Księdza Doktora sprawie: chodzi o powierzenie Ks. Doktorowi zastępstwa na katedrze historii dogmatów. Proszę zabrać ze sobą nast. dokumenty: świadectwo maturyczne; dyplom doktorski; spis prac naukowych; po jednym egzemplarzu każdej 
pracy naukowej; życiorys własnoręcznie napisany; zezwolenie ordynariusza na objęcie pracy w Ak. Teol. Kat. Oczekując spotkania zasyłam Księdzu Profesorowi serdeczne pozdrowienia.

(一) X. Ignacy Różycki, prodziekan.

$\dagger$ Olsztyn, 23 maja 1955.

Wielce Czcigodny Księże Dziekanie!

W odpowiedzi na pismo z 20 maja 1955 r. uprzejmie komunikuję, że objęcie proponowanego stanowiska jest dla mnie moralnie niemożliwe.

Łączę wyrazy głębokiej czci

(一) X. Julian Wojtkowski.

Odpowiedź doręczył osobiście adresatowi ks. dr Stanisław Zdanowicz, dojeżdżający z Olsztyna do Warszawy z wykładami prawa liturgicznego na Wydziale Prawa Kanonicznego ATK. Dalszej korespondencji w tej sprawie już nie było. Do postawy dystansu dołączyła się jeszcze chmura na czole ks. Ignacego Różyckiego. Natomiast ks. prof. Stefan Biskupski, wikariusz kapitulny warmiński i dziekan Wydziału Prawa Kanonicznego ATK, powiedział do ks. prof. Piotra Chojnackiego, dziekana Wydziału Filozofii Chrześcijańskiej ATK, w obecności niedoszłego i niewdzięcznego wykładowcy historii dogmatów, że „Akademia Teologii Katolickiej jest w grzechu poczęta”.

W tym samym okresie ks. Eugeniusz Florkowski interesował się nauką Stanisława Biedy z Łowicza o Niepokalanym Poczęciu NMP. Stało się to okazją do ożywienia korespondencji między nami od 11 kwietnia 1954 do 5 października 1955 roku. W tym ostatnim zawarte było następujące stwierdzenie: „Podobno proponowano Księdzu Profesorowi objęcie wykładów historii dogmatów w Akademii. Jakoś nie mogą znaleźć kandydata na tę posadę."

Mijały lata. Stolica Apostolska potwierdziła trwanie krakowskiego Wydziału Teologicznego w Seminarium Duchownym archidiecezji krakowskiej i nadała mu kształt Papieskiego Wydziału Teologicznego z wszystkimi uprawnieniami. Pierwszym dziekanem został ks. infułat Eugeniusz Florkowski, pierwszym wielkim kanclerzem arcybiskup metropolita krakowski Karol kard. Wojtyła.

W ciągu tych lat ogłosiłem drukiem: praca magisterska częściowo, rozprawa doktorska w całości oraz szereg artykułów historyczno-dogmatycznych, składających się na dwie większe całości: o kulcie Matki Boskiej w Polsce średniowiecznej ${ }^{3}$ i o dogmacie Wniebowzięcia Matki Boskiej na Wielkim Pomorzu

${ }^{3}$ Studia historyczno-dogmatyczne nad przedmiotem kultu Matki Boskiej w Polsce wieków XI - XV: Poczatki kultu Matki Boskiej w Polsce w świetle najstarszych rękopisów, „Studia Warmińskie” 1 : 1964 s. 215 - 257; Przedmiot liturgicznego kultu Matki Boskiej w Polsce XIII wieku, „Studia Warmińskie” 2 : 1965 s. 205-257; Kult Matki Boskiej w polskim piśmiennictwie do końca XV wieku, „Studia Warmińskie” 3 : 1966 s. 221 - 299. 
w średniowieczu 4 . Całość dorobku liczyła około czterdziestu pozycji z zakresu historii dogmatów, historii Kościoła i nauk pomocniczych historii. Dojrzała więc myśl o habilitacji, zaistniała możliwość przewodu na kościelnej wyższej uczelni teologicznej.

Pierwsza wizyta u dziekana Papieskiego Wydziału Teologicznego, ks. infułata Florkowskiego, w mieszkaniu przy ul. Kanonicznej, wypadła pomyślnie. Wielołokciowa bibliografia, spisana na arkuszach A4, doklejanych jeden pod drugim, okazała się wystarczająca. Formalny wniosek do Rady PWT w Krakowie o otwarcie przewodu habilitacyjnego złożony został 6 stycznia 1967 roku. Recenzentami zostali księża profesorowie: Eugeniusz Florkowski z PWT w Krakowie, Marian Rechowicz z KUL-u i Antoni Słomkowski z Akademickiego Studium Teologii Katolickiej w Warszawie. Recenzje wypadły pomyślnie, kolokwium zostały wyznaczone na dzień 9 czerwca 1968 roku w Metropolitalnym Seminarium Duchownym w Krakowie.

Kandydat w przeddzień złożył oficjalne wizyty wszystkim członkom rady profesorskiej Papieskiego Wydziału Teologicznego, zapraszając na kolokwium. Przyszli wszyscy. Była to, po ostatniej habilitacji ks. Karola Wojtyły na Wydziale Teologicznym Uniwersytetu Jagiellońskiego, pierwsza po wieloletniej przerwie habilitacja teologiczna w Krakowie. Spośród recenzentów nie było ks. Mariana Rechowicza, przebywającego w Wielkiej Brytanii. Miał żal, że na niego nie czekano, ale ks. Antoni Słomkowski postawil termin ostateczny, po którym odmawiał udziału w habilitacji.

Podczas przedstawiania dorobku naukowego przybył na kolokwium metropolita krakowski Karol kardynał Wojtyła. Omawianie dorobku zostało przerwane po pracach $\mathrm{z}$ historii dogmatów i historii Kościoła, a przed pracami z nauk pomocniczych, chociaż o pierwszym tomie glos wielkopolskich były już wówczas recenzje Stanisława Urbańczyka w „Języku Polskim” oraz A. Ujmy i W. Nowodworskiego w „Archiwach, Bibliotekach i Muzeach Kościelnych”. Część druga kolokwium, z zakresu mariologii historyczno-dogmatycznej, była mniej interesująca. Wykład habilitacyjny wówczas w ustawodawstwie polskim nie obowiązywał. W pewnym stopniu uzupełniłem ten brak wykładem inauguracyjnym roku akademickiego 1968/69 na Papieskim Wydziale Teologicznym w Krakowie o Engelhardzie z Langheim.

Głosowanie Rady Wydziału wypadło pozytywnie, szesnaście głosów za nadaniem stopnia docenta przy jednym wstrzymującym się. Nie było jeszcze wó-

${ }^{4}$ Studia Pomoraniae Assumptionistica: I. Wniebowzięcie Matki Bożej w świetle dziet kaznodziejskich należacych do ksiegozbioru Tomasza Wernera z Braniewa († 1498), „Roczniki Teologiczno-Kanoniczne" 12 : 1965 z. 2 s. 35 - 101; II. Wniebowzięcie Matki Bożej w zbiorach kazań należacych do duchownych z Pomorza Gdańskiego na przetomie XV i XVI wieku, ,Roczniki Teologiczno-Kanoniczne" 13 : 1966 z. 2 s. 93 - 111; III. Wniebowzięcie Matki Bożej w zbiorach kazań z biblioteki średniowiecznego klasztoru Franciszkanów w Gdańsku. IV. Wniebowzięcie Matki Bo$\dot{z} e j$ w świetle dziet kaznodziejskich ze średniowiecznych księgozbiorów kościelnych w Gdańsku i Kamieniu Pomorskim. V. Wiara we Wniebowzięcie Matki Bożej na terenie diecezji pomorskich w świetle średniowiecznych ksiąg liturgicznych, „Studia Warmińskie” 4:1967 s. 287-361. 
wczas rozróżnienia stopnia „doktor habilitowany” od etatu docenta. Dyplom podpisał metropolita krakowski kard. Karol Wojtyła, łącząc w ten sposób w jedną całość szereg docentów teologii Uniwersytetu Jagiellońskiego z szeregiem docentów Papieskiego Wydziału Teologicznego w Krakowie.

\author{
DIE ERSTE HABILITATION \\ AN DER PÄPSTLICHEN THEOLOGISCHEN FAKULTÄT KRAKAU
}

Zusammenfassung

Der Verfasser beschreibt die Geschichte eigener Habilitation, die im Jahre 1968 stattgefunden hat. Die Bedeutung dieser Habilitation liegt - unter anderem — im kirchlichen Charakter ihres Geschehens. Zum ersten Mal in ihrer Geschichte hat die polnische Kirche solchen Schritt ohne staatliche Anerkennung gewagt. Auf diese Weise nam sie in ihre Hände im totalitären Staatsystem die volle Verantwortung für die Entwicklung der kirchlichen Wissenschaften. 